\title{
Oxidation of Carbon Sources through the Tricarboxylic Acid Cycle in Mycobacterium leprae Grown in Armadillo Liver
}

\author{
By P. R. WHEELER \\ National Institute for Medical Research, Mill Hill, London NW7 1AA, UK
}

(Received 22 August 1983; revised 3 October 1983)

\begin{abstract}
All the enzymes of the tricarboxylic acid cycle have now been demonstrated in extracts of Mycobacterium leprae grown in armadillo liver. Many were also present in homogenates of hosttissue, but biochemical evidence is presented which indicates that all enzymes detected in extracts from $M$. leprae were authentic bacterial enzymes. Further evidence for a complete tricarboxylic acid cycle in $M$. leprae was obtained by first establishing that citrate could be taken up and catabolized by whole $M$. leprae organisms, then showing that oxidation of radioisotopically labelled pyruvate to $\mathrm{CO}_{2}$ by suspensions of $M$. leprae was stimulated by adding unlabelled citrate. Control of tricarboxylic acid cycle activity in $M$. leprae by the inactivation of fumarase by a protease is speculated upon.
\end{abstract}

\section{INTRODUCTION}

Knowledge of the catabolic pathways for possible carbon sources in Mycobacterium leprae is now becoming available. Glucose can be catabolized through glycolysis and the hexose monophosphate pathway, and glycerol is dissimilated through an intermediate, dihydroxyacetone phosphate, which is in the glycolysis pathway (Wheeler, 1982, 1983). Nevertheless, progress in elucidating metabolism in $M$. leprae is slow, as only $50-500 \mathrm{mg}$ dry weight bacteria are obtained from one heavily infected armadillo, the only really practicable source.

Information on oxidative metabolism in $M$. leprae is rather fragmentary. Cytochrome $o$, a bacterial cytochrome, has been reported in extracts of $M$. leprae (Ishaque et al., 1977); other cytochromes found in extracts may have been derived from host tissue. It is known that $\boldsymbol{M}$. leprae can oxidize succinate (Wheeler, 1982) and malate (Wheeler \& Bharadwaj, 1983), suggesting the presence of tricarboxylic acid cycle activity.

It has been suggested that $M$. lepraemurium lacks oxoglutarate dehydrogenase and therefore its tricarboxylic acid cycle has an anaplerotic function (Mori et al., 1971). Recent work suggests that $M$. lepraemurium (a slow-growing, intracellular organism like $M$. leprae) is not a good model for metabolism in M. leprae (Wheeler \& Gregory, 1980; Wheeler, 1982, 1983). However, other micro-organisms with specialized modes of growth have deletions of enzyme(s) in the Krebs cycle. Therefore the purpose of this study was to show whether or not the complete cycle operates in $M$. leprae. This involved looking for all the enzymes in extracts and testing whether rates of oxidation of substrates by intact $M$. leprae were stimulated by cycle intermediates. Before making comparisons of the operation of the Krebs cycle in $M$. leprae and $M$. lepraemurium, a further attempt to detect oxoglutarate dehydrogenase in $M$. lepraemurium was made.

\section{METHODS}

Micohacteria. Mycohacterium leprae and Micohacterium lepraemurium were harvested from armadillo liver and mouse spleen. respectively (Wheeler \& Gregory, 1980). Purified suspensions (Report, 1980) were prepared by tissue homogenization followed by treatment with DNAase and Percoll (Pharmacia) density-gradient

Ahbretiations: INT, $p$-iodonitrotetrazolium violet: NBT. nitroblue tetrazolium: PMSF, phenylmethylsulphonyl fluoride; TPP, thiamin pyrophosphate. 
centrifugation (only for $M$. leprae). When cell-free extracts were required, suspensions were further purified on an aqueous two-phase system $[7 \mathrm{~g}$ Dextran T500 (Pharmacia), $4.9 \mathrm{~g}$ polyethylene glycol $6000,0 \cdot 1 \mathrm{~g}$ polyethylene glycol monopalmitate, $0.01 \mathrm{M}-\mathrm{NaCl}, 0.01 \mathrm{~m}$-potassium phosphate ( $\mathrm{pH} \mathrm{6.9);} \mathrm{bacteria} \mathrm{suspended} \mathrm{in} \mathrm{buffered} \mathrm{Tween}$ (see below); and distilled water to $100 \mathrm{~g}$ in total (Report, 1980)]. Mycobacterium phlei NCTC 10266 was grown as described by Wheeler \& Gregory (1980). Cell-free extracts of mycobacteria were prepared by ultrasonication and centrifugation (Wheeler \& Gregory, 1980). Since thiols are required to preserve some enzyme activities, some suspensions of $M$. leprae organisms were disrupted in sonication buffer (Wheeler \& Gregory, 1980) containing $0 \cdot 1 \mathrm{mM}$-dithiothreitol (DTT). Enzymes were assayed in cell-free extracts prepared in the presence or absence of this thiol.

Extracts of host tissues. Liver tissue from uninfected armadillos or mice spleen was homogenized in $50 \mathrm{~mm}$ phosphate $\left(\mathrm{Na}_{2} \mathrm{HPO}_{4} / \mathrm{KH}_{2} \mathrm{PO}_{4}, \mathrm{pH} 7.5\right)$ buffer with $1 \mathrm{mM}-\mathrm{MgCl}_{2}$. Extracts of infected tissues were prepared from supernatants of the first homogenate $(0.2 \mathrm{M}$-Tris; $\mathrm{pH} \mathrm{8.7)}$ after centrifugation at $16000 \mathrm{~g}$ for $10 \mathrm{~min}$ during the preparation of pure mycobacteria (Wheeler \& Gregory. 1980).

$\mathrm{NaOH}$ treatment of $\mathrm{M}$. leprae. $\mathrm{NaOH}$ treatment of leprosy bacilli (Wheeler \& Gregory, 1980; Wheeler et al., 1982) and tubercle bacilli (Kanai, 1967) abolished adsorbed host-derived activity. Such treatment does not affect $M$. leprae viability (A. C. R. E. Lowe, personal communication). Suspensions of $M$. leprae were incubated in I $M^{-}$ $\mathrm{NaOH}$ for $1 \mathrm{~h}$ at $25^{\circ} \mathrm{C}$, as described by Wheeler et al. (1982).

Desalting of extracts. Desalted extracts from $M$. leprae and armadillo liver were prepared with Amicon CF25 centrifuge ultrafiltration cones $\left(700 \mathrm{~g}, 4{ }^{\circ} \mathrm{C}\right.$ : molecular weight cut off 25000$)$. After desalting, the salt concentration was $1 \%(\mathrm{w} / \mathrm{v})$ of the level in extracts that were not desalted.

Radioisotopes. 2-Oxo[5-1+C]glutaric acid, sodium salt $\left(15.9 \mathrm{mCi} \mathrm{mmol}^{-1} ; 0.58 \mathrm{GBq} \mathrm{mmol}{ }^{-1}\right),\left[6-^{-1+} \mathrm{C}\right] \mathrm{glucose}$ $\left(52.7 \mathrm{mCi} \mathrm{mmol}^{-1} ; 1.95 \mathrm{GBq}\right.$ mmol $\left.{ }^{1}\right),\left[2{ }^{-1}+\mathrm{C}\right]$ pyruvic acid $\left(18.3 \mathrm{mCi} \mathrm{mmol}^{-1} ; 0.68 \mathrm{GBq} \mathrm{mmol}^{-1}\right)$ and $[1,5-$ ${ }^{1+} \mathrm{C}$ ]citric acid $\left(111 \mathrm{mCi} \mathrm{mmol}^{\cdots 1}: 4 \cdot 11 \mathrm{GBq} \mathrm{mmol}^{-1}\right)$ were obtained from Amersham.

Incubations of $M$. leprae with radioisotopes. Bacteria (0.5-1.4 mg dry wt) were incubated with ${ }^{1+} \mathrm{C}$-labelled substrates as follows: glucose $-1 \mu \mathrm{Ci}, 0 \cdot 1 \mathrm{~mm}$; pyruvic acid $-0.37 \mu \mathrm{Ci}, 0 \cdot 1 \mathrm{~mm}$; and citric acid $-1 \mu \mathrm{Ci}, 0 \cdot 1 \mathrm{~mm}$. The incubation mixtures $(200 \mu \mathrm{l})$ also included HEPES (50 mM), $\mathrm{MgSO}_{4}(5 \mathrm{~mm})$, and $\mathrm{Na}_{2} \mathrm{HPO}_{4} / \mathrm{KH}_{2} \mathrm{PO}_{4}(\mathrm{pH} 7$; $1 \mathrm{~mm})$ adjusted to $\mathrm{pH} 7.0$ with $\mathrm{KOH}$. Additionally, penicillin $\left(50 \mathrm{U} \mathrm{ml}^{-1}\right)$ was added to prevent growth of any chance contamination in the incubation mixtures, but this did not affect metabolic activities. Incubations were done in Warburg flasks at $34{ }^{\circ} \mathrm{C}$ for $20 \mathrm{~h}$. The centre well contained $400 \mu \mathrm{ll} \mathrm{M}-\mathrm{NaOH}$ to absorb CO, evolved from oxidation of the substrate. Reactions were stopped by addition of $0.1 \mathrm{ml} 1.5 \mathrm{M}-\mathrm{H}_{2} \mathrm{SO}_{4}$ from a side-arm: $1 \mathrm{~h}$ later the $\mathrm{NaOH}$ was added to Ready-Solv EP (Packard)/distilled water $(10: 3, \mathrm{v} / \mathrm{v})$ for scintillation counting. After incubations with citrate, bacteria were collected and washed by centrifugation and resuspension until the supernatant was free of radioactivity. The final pellet was incubated for $1 \mathrm{~h}$ in Soluene-350 (Packard) at $37 \mathrm{C}$, then $10 \mathrm{ml}$ Dimilume-30 (Packard) was added. The amount of radioactivity assimilated was estimated by scintillation counting of this pellet. Results are expressed as d.p.m. per mg dry wt mycobacteria; when pure $M$. leprae organisms are dried and weighed. $10^{11}$ bacteria weigh approximately $1 \mathrm{mg}(\mathrm{R} . \mathrm{J}$. W. Rees, personal communication). Controls contained either no bacteria, or, for determination of assimilation. heat-killed $\left(100^{\circ} \mathrm{C}\right.$, $15 \mathrm{~min}$ ) bacteria. In the results, d.p.m. in controls are always subtracted.

Enzyme assay's and enzyme nomenclature. All enzymes were assayed in crude extracts at 25 "C: incubation volume was $500 \mu \mathrm{l}$ unless otherwise stated. Carboxylic acids were added as sodium salts, or free acids were used and adjusted to assay $\mathrm{pH}$ with $\mathrm{NaOH}$, unless otherwise stated.

Pyruvate dehydrogenase [EC 1.2.4.1: pyruvate:lipoamide oxidoreductase (decarboxylating and acceptoracetylating)] was assayed by a modification of the methods used by Murthy et al. (1962). Extracts were incubated

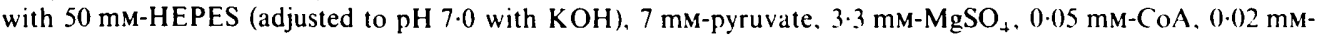
thiamin pyrophosphate (TPP) and $0.1 \mathrm{mM}$-DTT, plus either $0.09 \mathrm{mM}-\mathrm{NADP}$, in which case NADPH formation was followed by reading $\Delta A_{341}$, or $0.17 \mathrm{mM}-\mathrm{NAD}, 0.6 \mathrm{~mm}$-p-iodonitrotetrazolium violet (INT) and $0 \cdot 05$ units diaphorase (Sigma; from porcine heart), in which case reduction of INT was followed by reading $\Delta A_{5(1)}\left(\varepsilon_{1}^{1} \underset{\mathrm{m} m}{\mathrm{~cm}}=\right.$ $12 \cdot 6$ ).

Citrate synthase $\left[\right.$ EC 4.1.3.7: citrate oxaloacetate-lyase $\left(\right.$ pro- $-3 S-\mathrm{CH}_{2} \mathrm{COO} \rightarrow$ acetyl-CoA $\left.)\right]$ was assayed by a modification of the method of Weitzman (1969), with $100 \mathrm{~mm}$-Tris $/ \mathrm{HCl}(\mathrm{pH} 8.0), 3.75 \mathrm{mM}$-oxaloacetate, 0.05 mMacetyl CoA and $0 \cdot 1 \mathrm{~mm}-5.5$-dithiobis-(2-nitrobenzoic acid) (DTNB). The formation of the mercaptide ions of DTNB, stoichiometric with CoA formation, was followed by reading $\Delta A_{+12}\left(\varepsilon_{1}^{1} \mathrm{~cm}=13 \cdot 6\right)$.

Aconitase [EC 4.2.1.3; citrate (isocitrate) hydro-lyase] was activated and assayed by the method of Fansler \& Lowenstein (1969). Activation was in the presence of 5 mm-thiomalate Tris ( $\mathrm{pH} \mathrm{7-8)} \mathrm{and} 2$ mM-ferrous ammonium sulphate (the two solutions were gassed with nitrogen and kept separate until needed). Fnzyme assaly was with $20 \mathrm{~mm}$-Tris $/ \mathrm{HCl}\left(\mathrm{pH} \mathrm{7.4)}, 100 \mathrm{mM}-\mathrm{NaCl}\right.$ and $0.2 \mathrm{~mm}-\left(i s-a c o n i t a t e\right.$. The fall in $A_{2+1}$ due to disappearance of (isaconitate $(\varepsilon ! \mathrm{mu}=4 \cdot 88)$ was followed.

Isocitrate dehydrogenase [EC 1.1.1.42; threo-Ds-isocitrate: NADP oxidoreductase (decarboxylating)] was assayed by a modification of a method used for $M$. phlei (Dhariwal \& Venkitasubramanian, 1975), with 40 mM- 
Tris/ $\mathrm{HCl}\left(\mathrm{pH} \mathrm{7.3),} 5 \mathrm{~mm}-\mathrm{MgCl}_{2}, 0.33 \mathrm{~mm}-\mathrm{NADP}\right.$ and $3 \mathrm{mM}$-threo- $\mathrm{D}_{\mathrm{S}}$-isocitrate. NADPH formation was followed by reading $\Delta A_{340}$.

Oxoglutarate dehydrogenase [EC 1.2.4.2; 2-oxoglutarate:lipoamide oxidoreductase (decarboxylating and acceptor-succinylating)] was assayed by methods based on those used for $M$. tuberculosis (Murthy et al., 1962). The reaction mixture was $100 \mathrm{mM}-\mathrm{Na}_{2} \mathrm{HPO}_{4} / \mathrm{NaH}_{2} \mathrm{PO}_{4}(\mathrm{pH} 7 \cdot 2), 0.05 \mathrm{mM}-\mathrm{CoA}, 10 \mathrm{~mm}$-2-oxoglutarate, 0.33 mM-TPP and $1.5 \mathrm{mM}^{-\mathrm{MgSO}_{4}}$, plus either $0.33 \mathrm{mM}-\mathrm{NADP}$, in which case $\Delta A_{340}$ was followed, or $0.33 \mathrm{mM}-\mathrm{NAD}, 0.6 \mathrm{mM}-$ INT and 0.05 units diaphorase (Sigma; porcine heart), in which case $\Delta A_{500}$ was followed. Alternatively, the assay was done with $2-0 x 0\left[5-{ }^{+}+\mathrm{C}\right]$ glutarate $(1 \mu \mathrm{Ci} ; 2.5 \mathrm{~mm})$, in which case the reaction mixture was altered in that $25 \mathrm{~mm}$-phosphate buffer ( $\mathrm{pH} \mathrm{7.2)}$ was used and the volume was $25 \mu \mathrm{l}$. An alternative, radiochemical, assay included 2-oxo[5-1+C]glutarate $(1 \mu \mathrm{Ci} ; 2.5 \mathrm{~mm}), 25 \mathrm{~mm}$-phosphate buffer, 0.05 mM-CoA, 0.33 mM-TPP, $1.5 \mathrm{~mm}$ $\mathrm{MgSO}_{4}, 0.33 \mathrm{mM}-\mathrm{K}_{3} \mathrm{Fe}(\mathrm{CN})_{6}$, and $3.3 \mathrm{~mm}-\mathrm{KCN}$. In all radiochemical assays, $5 \mathrm{~mm}$-malonate, $0 \cdot 5 \mathrm{~mm}-\mathrm{GDP}$ and 0.05 units succinyl CoA synthetase (Sigma: from porcine heart) were included in the incubation mixture so that succinate was formed, but not oxidized. Succinate formed from 2-oxoglutarate was detected by stopping the reaction after $50 \mathrm{~min}$ with $4 \mu \mathrm{l} 6 \mathrm{M}-\mathrm{HCl}$, removing the precipitate by centrifugation, applying $12 \mu \mathrm{l}$ samples to Kodak-Eastman 'Chromogram' cellulose thin-layer chromatography plates together with $60 \mathrm{nmol}$ unlabelled carboxylic acids, developing with diethyl ether/acetic acid (glacial)/distilled water $(13: 3: 1$, by vol.), drying, spraying with acid -base indicator $\left[0.04 \mathrm{~g}\right.$ bromocresol green $\left(3^{\prime}, 3^{\prime \prime}, 5^{\prime}, 5^{\prime \prime}\right.$-tetrabromo- $m$-cresolsulphone-phthalein) in $96 \%$ ethanol $(100 \mathrm{ml}) ; 0.1 \mathrm{~m}-\mathrm{NaOH}$ added until a blue coloration just appeared], cutting out the spots corresponding to 2-oxoglutarate and succinate, and counting in $10 \mathrm{ml}$ Ready-Solv EP (Packard). The amount of succinate formed was calculated from the proportion of total counts in the succinate spot: controls included distilled water in place of extract.

Succinyl-CoA synthetase (EC 6.2.1 . 4: succinate : CoA ligase (GDP-forming)] was assayed by a modification of a method described by $\mathrm{Cha}$ (1969), with $50 \mathrm{mM}$-Tris/succinate ( $22.7 \mathrm{mM}$ with respect to succinate; $\mathrm{pH} 7.4$ ), $10 \mathrm{~mm}$ $\mathrm{MgCl}_{2}, 100 \mathrm{~mm}-\mathrm{KCl}, 0.1 \mathrm{~mm}-\mathrm{GTP}, 0.1 \mathrm{~mm}-\mathrm{CoA}, 1.5 \mathrm{~mm}$-phosphoenolpyruvate (tricyclohexammonium salt), $0.2 \mathrm{~mm}-\mathrm{NADH}$, and pyruvate kinase/lactate dehydrogenase mixture (Sigma, from rabbit muscle; $10 \mathrm{U} \mathrm{ml}^{-1}$ and $12.5 \mathrm{U} \mathrm{ml}^{-1}$ respectively). Oxidation of $\mathrm{NADH}$, stoichiometric with succinyl-CoA and GDP formation, was followed by reading $A_{3+0}$.

Succinate dehydrogenase (EC 1.3.99.1: succinate:acceptor oxidoreductase) was assayed with $25 \mathrm{mM}$ Tris/succinate (11.4 mM with respect to succinate: $\mathrm{pH} 7 \cdot 4), 1 \mathrm{~mm}-\mathrm{KCN}, 10 \mu \mathrm{M}$-phenazine methosulphate and $0.6 \mathrm{~mm}$-INT. Reduction of INT was followed by reading $\boldsymbol{A}_{5(\mathrm{~m})}$.

Fumarase (EC 4.2.1.2; fumarate hydro-lyase) was assayed by modifications of the method of Hill \& Bradshaw (1969), with $20 \mathrm{~mm}$-L-malate, $\mathrm{K}_{2} \mathrm{HPO}_{4}(50 \mathrm{~mm})$, adjusted to $\mathrm{pH} 7 \cdot 3$ with $\mathrm{NaOH}$. Alternatively, 1 mM-fumarate and $50 \mathrm{~mm}-\mathrm{K}_{2} \mathrm{HPO}_{4} / \mathrm{NaH}_{2} \mathrm{PO}_{4}$ buffer was used. In each case, appearance or disappearance of the double bond in fumarate was followed by reading $A_{2+0}\left(\varepsilon_{1}^{1} \mathrm{~mm}\right.$ for fumarate $\left.=2 \cdot 44\right)$.

Rate of reaction in the absence of substrate (i.e. in control incubations) was subtracted from rate of reaction in complete incubation mixtures. Enzyme activities were calculated from the initial velocity of the reaction. and expressed as units $(U)$ where one unit catalyses the conversion of $1 \mu \mathrm{mol}$ substrate $\min ^{-1}$. Inhibitors (all from Sigma) were added to extracts in assays before the coupling enzymes and $5 \mathrm{~min}$ before substrates.

$P A G E$. Extracts (150-300 $\mu \mathrm{g}$ protein) were applied to $7^{\circ}(\mathrm{w} / \mathrm{v})$ polyacrylamide gels and electrophoresed at about pH 6.5 (Chang et al. 1979). After electrophoresis the gels were washed in the buffer of the incubation medium for $15 \mathrm{~min}$, then incubated in the following. For detection of isocitrate dehydrogenase : $88 \mathrm{~mm}-\mathrm{Tris} / \mathrm{HCl}$ (pH 7.3), $10 \mathrm{~mm}-\mathrm{MnCl}_{2}, 0 \cdot 1 \mathrm{mM}$-NADP or NAD, 0.11 mM-phenazine methosulphate, $0 \cdot 78 \mathrm{~mm}$-3-(4,5-dimethylthiazol-2-yl)-2,5-diphenyltetrazolium bromide (MTT) and $6 \mathrm{mM}$-DL-isocitrate, for 3-4h. For detection of succinate dehydrogenase: $50 \mathrm{mM}$-Tris/succinate $(\mathrm{pH} \mathrm{7.4)}$ ( Tris/ $\mathrm{HCl}$ was used for controls with no substrate): $1 \mathrm{~mm}-\mathrm{KCN}, 0.07 \mathrm{~mm}$-phenazine methosulphate or FAD and $0.3 \mathrm{~mm}$-nitroblue tetrazolium (NBT).

Statistical analysis. The Wilcoxon (rank) test (Colquhoun, 1971) was used to test the following null hypotheses: (i) in experiments with enzyme inhibitors/activators, their effect on the activity being studied in both extracts of $M$. leprae and armadillo liver was identical (their effect was expressed as the percentage of the activity in a control incubation with no inhibitor/activator present); (ii) $\mathrm{CO}_{2}$ evolution, in experiments with radioisotopes, was not affected by the addition of unlabelled tricarboxylic acid cycle intermediates; (iii) $\mathrm{CO}_{2}$ evolution, in experiments with radioisotopes, was the same in controls and with live $M$. leprae.

\section{RESULTS}

\section{Pyrucate dehydrogenase and tricarboxylic acid cycle enzymes}

Pyrucate dehydrogenase. This enzyme was present at low specific activity in crude extracts of $M$. leprae: consequently it was not possible to detect it on polyacrylamide gels, nor to carry out studies with inhibitors. When TPP or CoA were omitted from incubations, no activity was 
Table 1. Activities of enzymes of the tricarboxylic acid cycle and pyruvate dehydrogenase

Values for specific activities in untreated $M$. leprae include assays done with extracts of $M$. leprae sonicated with $0.1 \mathrm{mM}$-DTT; in these extracts, specific activity was not markedly different from that in extracts without DTT. Values for specific activities in $\mathrm{NaOH}$-treated $M$. leprae represent assays done with one or two extracts of $\mathrm{NaOH}$-treated $M$. leprae. Values for specific activities in armadillo liver were determined by assaying extracts from liver homogenized at $\mathrm{pH} 7.5$ if activity could be detected in armadillo liver from infected tissue, which was homogenized at $\mathrm{pH} 8 \cdot 7$. Each figure represents an assay done at least in triplicate.

\begin{tabular}{|c|c|c|c|c|}
\hline \multirow[b]{2}{*}{ Enzyme } & \multicolumn{4}{|c|}{ Specific activity [mU (mg protein $)^{-1}$ ] in extracts of: } \\
\hline & $\begin{array}{l}\text { Untreated } \\
M \text {. leprae* }\end{array}$ & $\begin{array}{c}\mathrm{NaOH} \text {-treated } \\
M . \text { leprae }\end{array}$ & $\begin{array}{l}\text { Armadillo } \\
\text { liver }\end{array}$ & M. phlei \\
\hline dehydrogenase & 0.093 & 0.083 & nil $\dagger$ & $0 \cdot 80$ \\
\hline inthase & $0 \cdot 321$ & $0 \cdot 183$ & $12 \cdot 8$ & $5 \cdot 1$ \\
\hline & $13 \cdot 1$ & $9 \cdot 3$ & $4 \cdot 5$ & $52 \cdot 0$ \\
\hline dehydrogenase & $36 \cdot 4$ & $6 \cdot 1$ & $26 \cdot 7$ & ND \\
\hline rate dehydrogenase & $0 \cdot 17$ & $0 \cdot 14$ & nilt & $2 \cdot 0$ \\
\hline CoA synthetase & $4 \cdot 7$ & $5 \cdot 3$ & $21 \cdot 4$ & $5 \cdot 1$ \\
\hline dehydrogenase & $5 \cdot 4$ & $6 \cdot 2$ & 0.69 & $2 \cdot 9$ \\
\hline & $40 \cdot 7$ & $38 \cdot 3$ & 35.9 & $17 \cdot 5$ \\
\hline
\end{tabular}

ND, Not done.

* Contains some contaminating host enzymes (Wheeler et al., 1982).

$\dagger$ Limit of detection is $0.010 \mathrm{mU}(\mathrm{mg} \text { protein })^{-1}$.

Table 2. Differences between enzymes in extracts of $M$. leprae and armadillo liver

Extracts were assayed with inhibitors/activators of enzyme activity, or NADP in place of NAD, and the results are expressed as the percentage of the activity in incubations without inhibitor/activator, or with NAD, respectively. Each figure represents an assay done at least in triplicate. For isocitrate dehydrogenase and succinate dehydrogenase, differences between enzymes from extracts of $M$. leprae and armadillo liver were demonstrated by PAGE, followed by staining specifically for these enzymes (Fig. 1).

\section{Enzyme}

Pyruvate dehydrogenase $\dagger$

Citrate synthase

Aconitase

Oxoglutarate dehydrogenase $\dagger$

Succinyl-CoA synthetase

Fumarase
Property studied

Activity with NADP

Activity with $5 \mathrm{~mm}$-ATP

Activity with $0.1 \mathrm{mM}$-fluorocitrate

Activity with NADP

Activity with $10 \mathrm{~mm}-\mathrm{NH}_{2} \mathrm{OH}$

Inactivation by a protease from $M$. leprae $(6 \mathrm{~h})$

\begin{tabular}{|c|c|}
\hline \multicolumn{2}{|c|}{ Value obtained* } \\
\hline M. leprae & $\begin{array}{l}\text { Armadillo } \\
\text { liver }\end{array}$ \\
\hline nil & ND $\dagger$ \\
\hline $35 \%$ & $45 \%$ \\
\hline $40 \%$ & $60 \%$ \\
\hline $105 \%$ & NDt ${ }^{\circ}$ \\
\hline $40 \%$ & $125 \%$ \\
\hline $95 \%$ & $<15 \%$ \\
\hline
\end{tabular}

ND, Not done.

* Differences in properties were all significant $(P<0 \cdot 05)$ except with ATP inhibition of citrate synthase $(P>$ $0 \cdot 10)$.

† Enzyme not detected in armadillo liver extract. Activity of mammalian enzyme with NADP would be nil.

detected. In the absence of added DTT, activity was only $40 \%$ of that in the presence of DTT, except when extracts were made with DTT in the sonication buffer. The presence of this enzyme in extracts from $\mathrm{NaOH}$-treated $M$. leprae is evidence for its authenticity as a bacterial enzyme (Table 1). The chance of contamination with host enzyme was very low in any case, since the enzyme was not detected in infected armadillo liver tissue (Table 1).

Citrate synthase. ATP may be a more potent inhibitor of the $M$. leprae enzyme than the host enzyme, but this difference was not statistically significant $(P>0 \cdot 10)$ (Table 2). However, citrate synthase activity was detected in extracts of $\mathrm{NaOH}$-treated $M$. leprae (Table 1).

Aconitase. cis-Aconitate was included in incubations at a low concentration (Fansler \& Lowenstein, 1969) since a $1 \mathrm{~cm}$ light path and crude extracts with a high absorbance at $240 \mathrm{~nm}$ were used. Aconitase in extracts of $M$. leprae was readily detected by this method and was distinguished from the host enzyme (Table 2$)$ on the basis of its greater sensitivity $(P<0.05)$ to 


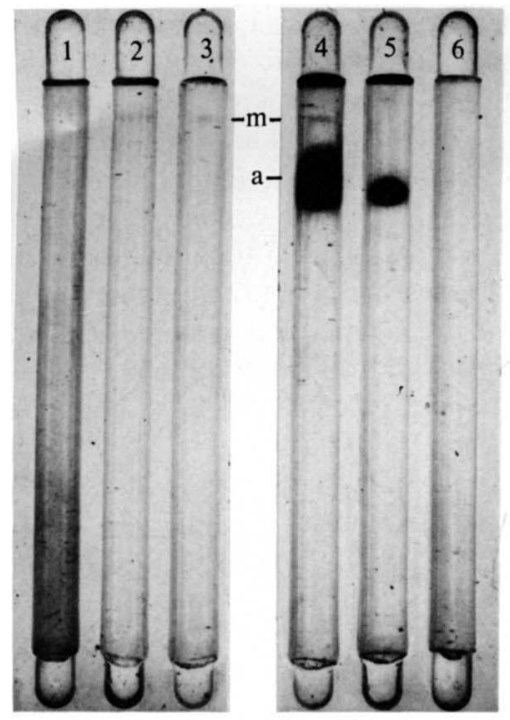

(a) Isocitrate dehydrogenase

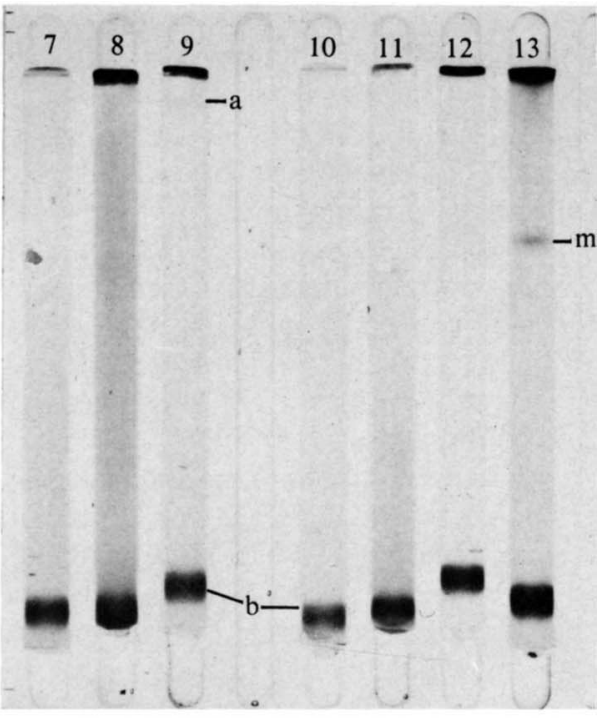

(b) Succinate dehydrogenase

Fig. I. PAGE of extracts on gels at pH 6.5. (a) Stained for isocitrate dehydrogenase (tracks 2-6) and compared with control (no substrates: track 1). NADP was the coenzyme in tracks 1-5, and NAD in track 6. Extracts (some gels with two applied together) were from: $M$. leprae (tracks 3, 4, 6); $\mathrm{NaOH}$ treated $M$. leprae (tracks 1, 2); uninfected armadillo liver (tracks 1, 4, 5, 6). (b) Stained for succinate dehydrogenase (tracks 8, 9, 10,12,13) and compared with controls (tracks 7, 11). Phenazine methosulphate was omitted in track 12. Extracts were from: $M$. leprae (tracks 11-13); uninfected armadillo liver (tracks 7-9) - this liver extract was ultrasonicated (11 min at $100 \mathrm{~W}$ ) by the method described for mycobacteria (Wheeler \& Gregory, 1980) in tracks 8 and 9. Controls (above) were all without enzyme substrate. $m$, denotes enzyme from $M$. leprae; a, denotes enzyme from armadillo liver: b, denotes bromophenol blue (marker; only visualized after staining when NBT was used).

inhibition by fluorocitrate (barium salt). Comparisons of enzyme activities in different extracts were made with non-activated extracts (Tables 1 and 2$)$. After activation $\left(25^{\circ} \mathrm{C}, 30 \mathrm{~min}\right), 38 \mathrm{mU}$ aconitase (mg protein $)^{-1}$ was detected in the extract from $\mathrm{NaOH}$-treated $M$. leprae.

Isocitrate dehydrogenase. The NADP-dependent enzyme was detected in extracts of both $M$. leprae and armadillo liver. On gels, it was shown that the enzymes from these two sources had different electrophoretic mobilities (Fig. 1, tracks 2-5), and that there was no activity in either extract when NAD was substituted for NADP (Fig. 1, track 6).

Oxoglutarate dehydrogenase. The values for specific activity in Table 1 were derived from results with both the spectrophotometric and the radioisotopic method, with NAD in the incubation mixture. The values obtained were similar with the two methods, although the concentration of substrate was $10 \mathrm{~mm}$ and $2.5 \mathrm{~mm}$ respectively. The reaction rate was linear up to $100 \mathrm{~min}$ in the spectrophotometric assay. The comparison between activity with NADP and NAD (Table 2) was made with the radioisotopic method only. When ferricyanide was used in place of the pyridine nucleotides, the rate of appearance of succinate, in incubations including $M$. leprae extracts, was enhanced by $50 \%$.

This enzyme was also detected in extracts of $M$. lepraemurium. The rate was noticeably more rapid in the first $4 \mathrm{~min}$ (spectrophotometric method), and specific activities in extracts calculated after $4 \mathrm{~min}$ (six incubations) were: from untreated bacteria, $0.63 \mathrm{mU}(\mathrm{mg} \text { protein })^{-1}$; from $\mathrm{NaOH}$-treated bacteria, $0 \cdot 22 \mathrm{mU}$ (mg protein $)^{-1}$. Lower values $(50 \%$ of total above) were calculated from the radioisotopic method, by which it could be shown that both bacterial extracts used NADP as coenzyme at $80 \%$ the rate of NAD. No activity was detected in an extract of mouse spleen.

The low activity in extracts, and complex requirement for cofactors, made it impossible to detect the enzyme from $M$. leprae or $M$. lepraemurium on gels. 
Succinyl-CoA synthetase. This enzyme was present at a relatively high specific activity in extracts of $M$. leprae (Table 1). It was inhibited by $10 \mathrm{mM}$-hydroxylamine $\left(\mathrm{NH}_{2} \mathrm{OH}\right)$, in contrast to the activity in extracts from armadillo liver, which was slightly increased (Table 2).

Succinate dehydrogenase. Activity at the level shown in Table 1 could be measured in extracts of $M$. leprae even if phenazine methosulphate was omitted from the reaction mixture. However, a band of activity corresponding to $M$. leprae succinate dehydrogenase was only detected on gels (after electrophoresis) when phenazine methosulphate was included in the incubation mixture (Fig. 1). Succinate dehydrogenase in armadillo liver extracts did not migrate into gels unless the extracts were sonicated $(11 \mathrm{~min}, 100 \mathrm{~W}$, as for $M$. leprae organisms) before electrophoresis: the activity observed after sonication had a different mobility from the activity in extracts of $\boldsymbol{M}$. leprae (Fig. 1, tracks 9 and 13). No bands were detected when FAD was substituted for phenazine methosulphate.

Fumarase. In these studies, fumarase in extracts of $M$. leprae was the only enzyme activity to decrease appreciably after storage at $4{ }^{\circ} \mathrm{C}$ (activity was retained, as for the other enzymes, when extracts were stored at $-80^{\circ} \mathrm{C}$ ). This inactivation was $95 \%$ of the original activity in extracts from $\mathrm{NaOH}$-treated $M$. leprae in $6 \mathrm{~h}$ (Table 2) but it could be inhibited by addition of $0.2 \mathrm{~mm}$ phenylmethylsulphonyl fluoride (PMSF: added from a $5 \mathrm{~mm}$ stock solution in dimethyl sulphoxide immediately on thawing extracts) - inactivation was $30 \%$ in $6 \mathrm{~h}$. In contrast only $20 \%$ loss of activity of fumarase in armadillo liver extract, not preventable by addition of $0.2 \mathrm{mM}$-PMSF, occurred over $6 \mathrm{~h}$ at $4{ }^{\circ} \mathrm{C}$. When an extract of $\mathrm{NaOH}$-treated $M$. leprae and an extract of armadillo liver (both freshly thawed) were mixed in the ratios (by weight, protein) $1: 4$ or $2: 1$, the inactivation of the fumarase from armadillo liver was $35 \%$ in both mixtures over $6 \mathrm{~h}$ at $4{ }^{\circ} \mathrm{C}$. The result with the latter mixture was from triplicate incubations. When $0 \cdot 2 \mathrm{mM}-\mathrm{PMSF}$ was added to the second mixture, inactivation was $28 \%$. Differences between (i) liver extract and (ii) liver extract/ $M$. leprae extract mixture \pm PMSF can be used to calculate inactivation over $6 \mathrm{~h}$ of the liver fumarase due to mixing with $\boldsymbol{M}$. leprae extract; the maximum value was $15 \%$ inactivation. In a mixture ( $1: 1$ by weight, protein) of $M$. phlei extract and $M$. leprae extract (stored at $4{ }^{\circ} \mathrm{C}$ for $2 \mathrm{~h}$ ), fumarase activity from $M$. phlei was lost at the same rate as fumarase activity in an $M$. phlei extract only. The loss of activity in both the mixture or the $M$. phlei extract alone was $40 \%$ of the original $M$. phlei activity in $6 \mathrm{~h}$, and was not inhibited by PMSF.

\section{Catabolism of substrates by unbroken $M$. leprae}

$\left[{ }^{14} \mathrm{C}\right]$-labelled citrate and succinate were both taken up and catabolized to $\mathrm{CO}_{2}$ by suspensions of purified $M$. leprae (Table 3). Citrate and glutamate (known to be a substrate for M. leprae; Prabhakaran \& Braganca, 1962) were then used to supply tricarboxylic acid cycle intermediates, and to determine whether their addition to suspensions of $M$. leprae stimulated glucose and pyruvate oxidation. ${ }^{14} \mathrm{CO}_{2}$ evolution with suspensions of $M$. leprae plus either $\left[6-{ }^{14} \mathrm{C}\right]$ glucose or $\left[2-{ }^{14} \mathrm{C}\right]$ pyruvate was measured (Table 3 ) with and without the two cycle intermediates (all at $0.1 \mathrm{~mm}$ ). Only pyruvate oxidation was stimulated; mean d.p.m. in $\mathrm{CO}_{2}$ evolved was similar when citrate or glutamate was added, representing $\sim 50 \%$ stimulation. However, only the stimulation by citrate was statistically significant $(P<0.05)$.

\section{DISCUSSION}

All the enzymes of the tricarboxylic acid cycle have been demonstrated in extracts of $M$. leprae. They could all be detected at similar levels in extracts from untreated and $\mathrm{NaOH}$-treated $M$. leprae, although isocitrate dehydrogenase was present in $\mathrm{NaOH}$-treated $M$. leprae at $17 \%$ the level in untreated $M$. leprae. This degree of inactivation may reflect the location of isocitrate dehydrogenase in $M$. leprae at a (surface?) site where it is exposed to $\mathrm{NaOH}$ treatment since electrophoresis shows clearly that isocitrate dehydrogenase in untreated $M$. leprae is not hostderived (Fig. 1). Enzyme activities adsorbed to mycobacteria from host tissue are completely abolished by $\mathrm{NaOH}$ treatment (Kanai, 1967; Wheeler \& Gregory, 1980; Wheeler et al., 1982). Since two of the enzyme activities are higher in $\mathrm{NaOH}$-treated than untreated $M$. leprae (Table 1 ) it is suggested that the differences between activities in treated and untreated $M$. leprae reflect 
Table 3. Effect of tricarboxylic acid cycle intermediates on oxidation of carbon sources

Incubations were for $20 \mathrm{~h}$, with untreated, intact $M$. leprae. No $\mathrm{CO}_{2}$ was evolved when extract from $\boldsymbol{M}$. leprae or armadillo liver was substituted for the whole bacteria. Both labelled and unlabelled substrates were at $0 \cdot 1 \mathrm{~mm} ; 1 \mu \mathrm{Ci}$ radiolabel was included except in the case of $[2-1+\mathrm{C}]$ pyruvate $(0 \cdot 37 \mu \mathrm{Ci})$. Values in the table were subtracted from values obtained with heat-killed controls or ( $\mathrm{CO}_{2}$ evolved only) controls with no bacteria. All were significantly above control values $(P<0.01$ except when indicated). At least four controls and nine incubations (except with glucose, three and six respectively) with live $M$. leprae were done. No significant differences were observed between metabolic activities in $M$. leprae from different tissues.

$\begin{array}{llc}\text { Labelled* } & \text { Unlabelled } & \begin{array}{c}\mathrm{CO}_{2} \text { evolved } \\ \text { (d.p.m. per mg M. leprae) }\end{array} \\ \text { Glucose } & \text { None } & 2650 \\ \text { Glucose } & \text { Citrate } & 2460 \\ \text { Glucose } & \text { Glutamate } & 2770 \\ \text { Pyruvate } & \text { None } & 4150 \dagger \\ \text { Pyruvate } & \text { Citrate } & 6170 \\ \text { Pyruvate } & \text { Glutamate } & 6230 \\ \text { Citrate } & \text { None } & 2930 \dagger_{+}^{+}\end{array}$

* Distribution of radioisotopic labelling was selected to avoid, as far as possible, ${ }^{1+} \mathrm{CO}_{2}$ evolution without catabolism in the tricarboxylic acid cycle.

+ Assimilation (d.p.m. per mg M. leprae) was 2600 for pyruvate and 3060 for citrate.

$\ddagger P<0.05$.

variation in the preparation of different extracts and do not constitute evidence for the removal of residual Krebs cycle enzymes from the host. Activity varied widely from enzyme to enzyme, both in terms of units and relative to $M$. phlei (Table 1). However, no significance could be attached to this variation, which could be a result of assaying the enzymes in very different conditions to those in the living organism. For instance, enzymes of the tricarboxylic acid cycle are generally attached to membranes in bacteria (Doelle, 1975). In these experiments, very little activity is attached to membranes (as shown by successful electrophoresis of the enzymes) after the ultrasonication treatment used to disrupt the mycobacteria.

It was possible to demonstrate at least one difference between enzymes in extracts of $M$. leprae and armadillo liver, when activity could be detected in host tissue. Pyruvate and oxoglutarate dehydrogenases were not detectable in armadillo liver homogenized in Tris at pH 8.7 (Table 1) but a property of these dehydrogenases in some bacteria - the ability to use NADP as well as NAD - could be shown in $M$. leprae. Many of the tricarboxylic acid cycle enzymes were at low levels in the extract of host-tissue, and this may be a result of using homogenization methods unsuitable for the isolation of mitochondrial enzymes. In this context, the isocitrate dehydrogenase detected from host tissue was the NADP-dependent cytoplasmic enzyme. Mitochondrial, NAD-dependent isocitrate dehydrogenase was not detected (Fig. 1).

An 'incomplete Krebs cycle' in micro-organisms is generally a result of the deletion of oxoglutarate dehydrogenase (Doelle, 1975). This has been suggested for $M$. lepraemurium (Mori et al., 1971) so it was of particular interest to demonstrate this enzyme in $M$. leprae (Table 1). However, the enzyme was also detected in extracts of $M$. lepraemurium during this work. Oxoglutarate dehydrogenase in extracts of both bacteria was demonstrated by NAD and NADP reduction in the presence of oxoglutarate, and formation of succinate in incubations with oxo[5${ }^{14} \mathrm{C}$ lglutarate. There is a risk that $\mathrm{NaOH}$ treatment may remove enzymes of $M$. leprae located in the surface as well as activities adsorbed from the host and it is possible that Mori and coworkers abolished the $M$. leprae-derived activity by their $\mathrm{NaOH}$-treatment; in this work similar treatment of $M$. lepraemurium abolished $62 \%$ of the activity.

Further evidence for the complete nature of the tricarboxylic acid cycle in $M$. leprae was obtained by showing that pyruvate oxidation (to $\mathrm{CO}_{2}$ ) could be stimulated by citrate (Table 3 ). This observation was made with pyruvate radioisotopically labelled in such a position (C-2) that ${ }^{14} \mathrm{CO}_{2}$ would be evolved in Krebs cycle rather than in the reaction catalysed by pyruvate dehydrogenase. It replaced the classical demonstration of Krebs cycle activity in which 
endogenous or pyruvate-dependent $\mathrm{O}_{2}$ uptake is catalytically stimulated by a cycle intermediate. The evolution of ${ }^{14} \mathrm{CO}_{2}$ from $\left[6-{ }^{14} \mathrm{C}\right]$ glucose is almost completely dependent upon tricarboxylic acid cycle activity - the alternative possibility for limited ${ }^{14} \mathrm{CO}_{2}$ release is extensive cycling through the hexose monophosphate pathway (Wood, 1955), which can be neglected in $M$. leprae where hexose monophosphate pathway activity is limited (Wheeler, 1983). Evolution of $\mathrm{CO}_{2}$ was not stimulated by citrate or glutamate, but it is possible that some enzymes in the EmbdenMeyerhoff pathway, through which most glucose is catabolized in $M$. leprae (Wheeler, 1983), are inhibited by cycle intermediates.

Previous research on anaerobic pathways of carbon metabolism (Wheeler, 1982, 1983) and oxidation of malate (Wheeler \& Bharadwaj, 1983), and the present work, suggest that $M$. leprae is competent in its ability to catabolize different carbon sources such as glucose, glycerol and 6phosphogluconate completely to $\mathrm{CO}_{2}$. Thus, failure to cultivate the leprosy bacillus appears not to be related to difficulty in finding suitable substrates for energy production. However, metabolic activity of suspensions of $M$. leprae is low and the growth of $M$. leprae is very slow. The low levels of enzymes in extracts of $M$. leprae relative to other mycobacteria may be related to these observations. An interesting observation is that there is a protease (evidence for the protease nature of the activity is restricted to its inhibition by PMSF) in extracts of $M$. leprae which has been shown to act only against the fumarase of $M$. leprae. Loss of activity of other tricarboxylic acid cycle enzymes in extracts of $M$. leprae was not noticeable, and fumarases in extracts of armadillo liver or $M$. phlei were not inactivated when those extracts were mixed with $M$. leprae. It may be possible for this protease to control Krebs cycle activity, and therefore the rate of catabolism of substrates in $M$. leprae, if the protease can inactivate fumarase in the living organism as well as in extracts in experimental conditions.

I thank M. J. Colston and P. Draper for helpful discussion and D. W. Gregory for technical assistance. LEPRA (British Leprosy Relief Association) provided funds for maintaining the colony of armadillos.

\section{REFERENCES}

CHA, S. (1969). Succinate thiokinase from pig heart. Methods in Enzymology 13, 62-69.

Chang, P. L., Ballantyne, S. R. \& Davidson, R. G. (1979). Detection of arylsulphatase-A activity, after electrophoresis in polyacrylamide gel electrophoresis: problems and solutions. Analytical Biochemistry 97, 36-42.

Colquhoun, D. (1971). Numerical and rank measurements. In Lectures on Biostatistics, pp. 137-151. Oxford: Clarendon Press.

Dhariwal, K. R. \& Venkitasubramanian, T. A. (1975). Regulation of tricarboxylic acid cycle dehydrogenases in Mycobacterium phlei. Indian Journal of Biochemistry and Biophysics 12, 283-284.

DOELLE, H. W. (1975). Aerobic respiration - chemoorganotrophic bacteria. In Bacterial Metabolism, 2nd edn, pp. 380-491. New York: Academic Press.

FansleR, B. \& Lowenstein, J. M. (1969). Aconitase from pig heart. Methods in Enzymology 13, 26-30.

HiLl, R. L. \& BRAdShaw, R. A. (1969). Fumarase. Methods in Enzymology 13, 91-99.

Ishaque, M., Kato, L. \& SKinsnes, O. K. (1977). Cytochrome-linked respiration in host grown $M y$ cobacterium leprae. International Journal of Leprosy 45, $114-119$.

KANAI, K. (1967). Detection of host-originated acid phosphatase on the surface of in vivo grown tubercule bacilli. Japanese Journal of Medical Science and Biology 20, 73-90.

Mori, T., Kohsaka, K. \& TANAKA, Y. (1971).
Tricarboxylic acid cycle in Mycobacterium lepraemurium International Journal of Leprosy 39, 796-812.

MURTHY, P. S., SISRI, M. \& RAMAKRISHNAN, T. (1962). Tricarboxylic acid cycle and related enzymes in cellfree extracts of Mycobacterium tuberculosis $\mathrm{H}_{37} \mathrm{Rv}$. Biochemical Journal 84, 263-269.

Prabhakaran, K. \& Braganca, B. M. (1962). Glutamic acid decarboxylase activity of Mycobacterium leprae and occurrence of $\gamma$-aminobutyric acid in skin lesions of leprosy. Nature, London 196, 589-590.

REPORT (1980). UNDP/World Bank/WHO Special Programme for Research and Training in Tropical Diseases. Report of the Fifth Meeting of the Scientific Working Group on the Immunology of Leprosy (IMMLEP). TDR/IMMLEP-SWG(5)/80.3, Annex 4, p. 23. Geneva: World Health Organization.

Weitzman, P. D. J. (1969). Citrate synthase from Escherichia coli. Methods in Enzymology 13, 22-26.

WHEELER, P. R. (1982). Metabolism of carbon-sources by Mycobacterium leprae. A preliminary report. Annales de microbiologie 133B, 141-146.

WhEeler, P. R. (1983). Catabolic pathways for glucose, glycerol and 6-phosphogluconate in $\mathrm{Myco}$ bacterium leprae grown in armadillo tissues. Journal of General Microbiology 129, 1481-1485.

WheEler, P. R. \& BharadWaJ, V. P. (1983). Enzymes of malate oxidation in Mycobacterium leprae grown in armadillo liver. Journal of General Microbiology 129, 2321-2325.

WheEler, P. R. \& Gregory, D. (1980). Superoxide 
dismutase, peroxidatic activity and catalase in Mycobacterium leprae purified from armadillo liver. Journal of General Microbiology 121, 457-464.

WheEler, P. R., BharadWaJ, V. P. \& Gregory, D. (1982). $N$-Acetyl- $\beta$-glucosaminidase, $\beta$-glucuroni- dase and acid phosphatase in Mycobacterium leprae. Journal of General Microbiology 128, 1063-1071.

WoOD, H. G. (1955). Significance of alternate pathways in the metabolism of glucose. Physiological Reviews 35, 841-859. 